Original Research Paper

\title{
Switching from Flat to Spatial Motion to 3R Mechatronic Systems
}

\author{
${ }^{1}$ Relly Victoria Petrescu, ${ }^{2}$ Raffaella Aversa, \\ ${ }^{2}$ Antonio Apicella and ${ }^{1}$ Florian Ion Tiberiu Petrescu \\ ${ }^{1}$ ARoTMM-IFToMM, Bucharest Polytechnic University, Bucharest, (CE), Romania \\ ${ }^{2}$ Advanced Material Lab, Department of Architecture and Industrial Design, \\ Second University of Naples, 81031 Aversa (CE), Italy
}

Article history

Received: 11-01-2018

Revised: $16-01-2018$

Accepted: 22-01-2018

Corresponding Author: Florian Ion Tiberiu Petrescu ARoTMM-IFToMM, Bucharest Polytechnic University, Bucharest, (CE), Romania E-mail: scipub02@gmail.com
Abstract: The anthropomorphic robots are part of the classical series of mechatronic systems, being in the form of arms and having at least three space rotation, to which other components may eventually be added, thus lengthening the entire kinematic chain. You can also add all the planetary or spatial rotating arms or others that are translating. At the end we always have the end effector element that can be a manipulator, that is, a hand to grasp the objects, in which case one can speak of a prehensive device, that is a gripping device that today imitates very well a human hand even if it is one mechanical, may also be a painting, cutting or welding device, or one for machining. The base support and schematics of all anthropomorphic robots remain the $3 \mathrm{R}$ space system. It has been presented in other works and studied matrix spatially, or more simply in a plan, but in this case, it is necessary to move from the working plane to the real space, or vice versa, passage that we will present in this study. Projections of point $M$ on planar axes will be marked with the higher $P$ (Plan) index to distinguish them from the corresponding space axes. Due to the fact that the vertical projection plane is removed from the $O \rho$ axis with a constant distance $a_{2}+a_{3}$, (the vertical working plane does not project directly on the $O \rho$ axis, but on an axis parallel to it distal to the length $a_{2}+a_{3}$ ) the projection of the $M$ point on the horizontal plane of the space will not fall in $M$ 'but at the point $M^{\prime}$. Therefore, the projections of $M$ on the axes $O x$ and $O y$ will not be those of point $M$ but those of point $M^{\prime \prime}$, according to the relations given by the system (2). We want to remove the angle of $90^{\circ} \mathrm{C}$ from the relations (2), which had an important explanatory role in the understanding of the phenomenon, to see how the equation of transition from plane to spatial axes is written, here (in the horizontal plane of space) about a rotation, whose relations should not be automatically detained, but deduced logically, which is why we will immediately move from the logically determined system (2) to the convenient system (3), which will now be obtained from (2) the angle of $90^{\circ} \mathrm{C}$ from the trigonometric relations. Perhaps the method used may seem rather difficult, but compared to spatial matrix methods, it is extremely straightforward and direct, contributing to transforming the space movement into a flat, much easier to understand and studied movement. In the system (4) we centralize all the transition relations from the plane to the spatial movement.

Keywords: Anthropomorphic Mechatronic Systems, Robots, Geometry, Kinematics, Switching from Flat to Spatial Motion 


\section{Introduction}

Anthropomorphic mechatronic systems are the most widely used robotics systems worldwide today in industry and in all automated environments. These systems are best suited to the modern automation and mechatronisation needs of the modern world, being mobile, dynamic, light, robust, complex, technologically simple, easy to design and manufactured, implemented, maintained and used in almost any industrial site, both in machine building and in special environments, such as chemical, toxic, dyeing, underwater, nuclear, in space.... Anthropomorphic robots are flexible, dynamic, stable, lightweight, fast, fast, inexpensive, easy-to-install, mechanical, mechanical, mechanical and mechanical systems with a pleasant appearance, modern industrial design and easy to design and implement in any workplace, imposed. The anthropomorphic robots are part of the classical series of mechatronic systems, being in the form of arms and having at least three space rotation, to which other components may eventually be added, thus lengthening the entire kinematic chain. You can also add all the planetary or spatial rotating arms or others that are translating. At the end we always have the end effector element that can be a manipulator, that is, a hand to grasp the objects, in which case one can speak of a prehensive device, that is a gripping device that today imitates very well a human hand even if it is one mechanical, may also be a painting, cutting or welding device, or one for machining. The base support and schematics of all anthropomorphic robots remain the $3 R$ space system. It has been presented in other works and studied matrix spatially, or more simply in a plan, but in this case, it is necessary to move from the working plane to the real space, or vice versa, passage that we will present in this study (Antonescu and Petrescu, 1985; 1989; Antonescu et al., 1985a; 1985b; 1986; 1987; 1988; 1994; 1997; 2000a; 2000b; 2001; Aversa et al., 2017a; 2017b; 2017c; 2017d; 2017e; 2016a; 2016b; 2016c; 2016d; 2016e; 2016f; 2016g; 2016h; 2016i; 2016j; 2016k; 2016l; 2016m; 2016n; 2016o; Berto et al., 2016a; 2016b; 2016c; 2016d; Cao et al., 2013; Dong et al., 2013; Comanescu, 2010; Franklin, 1930; He et al., 2013; Lee, 2013; Lin et al., 2013; Liu et al., 2013; Mirsayar et al., 2017; Padula and Perdereau, 2013; Perumaal and Jawahar, 2013; Petrescu, 2011; 2015a; 2015b; Petrescu and Petrescu, 1995a; 1995b; 1997a; 1997b; 1997c; 2000a; 2000b; 2002a; 2002b; 2003; $2005 \mathrm{a} ; 2005 \mathrm{~b} ; 2005 \mathrm{c} ; 2005 \mathrm{~d} ; 2005 \mathrm{e} ; 2011 ; 2012 \mathrm{a}$; 2012b; 2013a; 2013b; 2016a; 2016; 2016c; Petrescu et al., 2009; 2016; ; 2017a; 2017b; 2017c; 2017d; 2017e; 2017f; $2017 \mathrm{~g} ; 2017 \mathrm{~h} ; 2017 \mathrm{i} ; 2017 \mathrm{j} ; 2017 \mathrm{k} ; 2017 \mathrm{l} ; 2017 \mathrm{~m}$; 2017n; 2017o; 2017p; 2017q; 2017r; 2017s; 2017t; 2017u; 2017v; 2017w; 2017x; 2017y; 2017z; 2017aa; 2017ab; 2017ac; 2017ad; 2017ae).

\section{Materials and Methods}

Figure 1 shows the kinematic diagram of the planar chain and Fig. 2 shows the kinematic scheme of the space chain.

The transition from the plane to the space movement will then be continued.

The $x_{2} \mathrm{Oy}_{2}$ plane dimensions will be projected onto the $z O \rho$ axes. Thus, the length on the horizontal vertical axis $O y$ will be projected onto the spatial vertical axis $O z$ by adding the constant $a_{1} \varphi$ and the length of the horizontal plan axis $O x$ will be projected on the horizontal spatial axis $O \rho$ by adding the constant $d_{1}$, according to the relations given by the system (1):

$\left\{\begin{array}{l}\rho_{M^{\prime}}=d_{1}+x_{M}^{P} \\ z_{M}=a_{1}+y_{M}^{P}\end{array}\right.$

Projections of point $M$ on planar axes will be marked with the higher $P$ (Plan) index to distinguish them from the corresponding space axes.

Due to the fact that the vertical projection plane is removed from the $O \rho$ axis with a constant distance $a_{2}+$ $a_{3}$, (the vertical working plane does not project directly on the $O \rho$ axis, but on an axis parallel to it distal to the length $a_{2}+a_{3}$ ) the projection of the $M$ point on the horizontal plane of the space will not fall in $M$ 'but at the point $M^{\prime \prime}$ (Fig. 2).

Therefore, the projections of $M$ on the axes $O x$ and $O y$ will not be those of point $M$ but those of point $M^{\prime \prime}$, according to the relations given by the system (2):

$\left\{\begin{array}{l}x_{M}=\rho_{M^{\prime}} \cdot \cos \varphi_{10}+\left(a_{2}+a_{3}\right) \cdot \cos \left(\varphi_{10}+\frac{\pi}{2}\right) \\ y_{M}=\rho_{M^{\prime}} \cdot \sin \varphi_{10}+\left(a_{2}+a_{3}\right) \cdot \sin \left(\varphi_{10}+\frac{\pi}{2}\right)\end{array}\right.$

We want to remove the angle of $90^{\circ} \mathrm{C}$ from the relations (2), which had an important explanatory role in the understanding of the phenomenon, to see how the equation of transition from plane to spatial axes is written, here (in the horizontal plane of space) about a rotation, whose relations should not be automatically detained, but deduced logically, which is why we will immediately move from the logically determined system (2) to the convenient system (3), which will now be obtained from (2) the angle of $90^{\circ} \mathrm{C}$ from the trigonometric relations:

$\left\{\begin{array}{l}x_{M}=\rho_{M^{\prime}} \cdot \cos \varphi_{10}-\left(a_{2}+a_{3}\right) \cdot \sin \varphi_{10} \\ y_{M}=\rho_{M^{M}} \cdot \sin \varphi_{10}+\left(a_{2}+a_{3}\right) \cdot \cos \varphi_{10}\end{array}\right.$ 


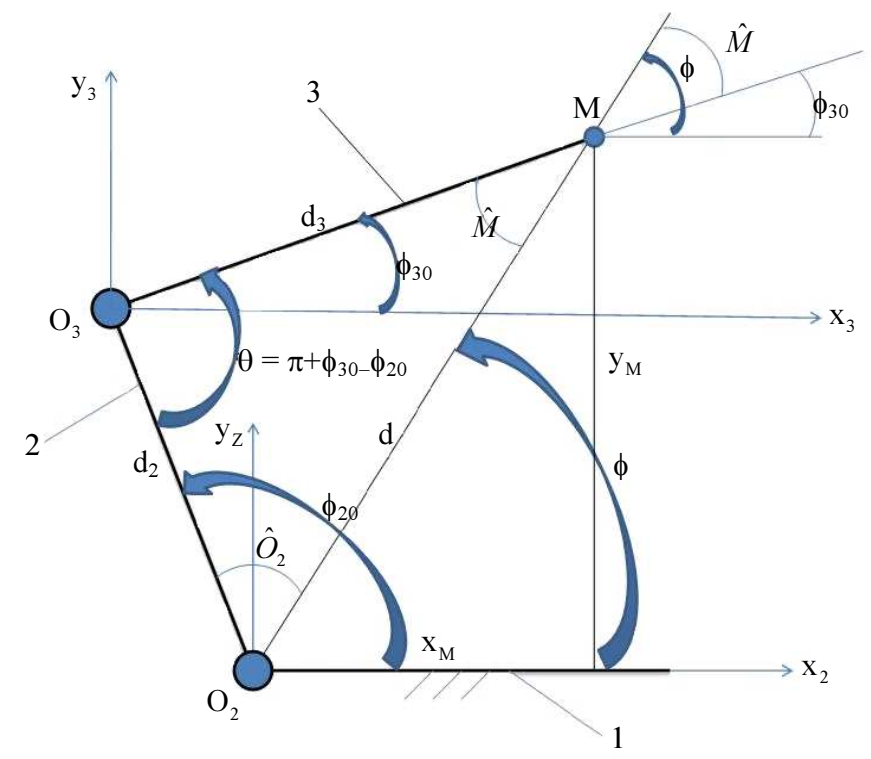

Fig. 1: The kinematic scheme of the plan chain

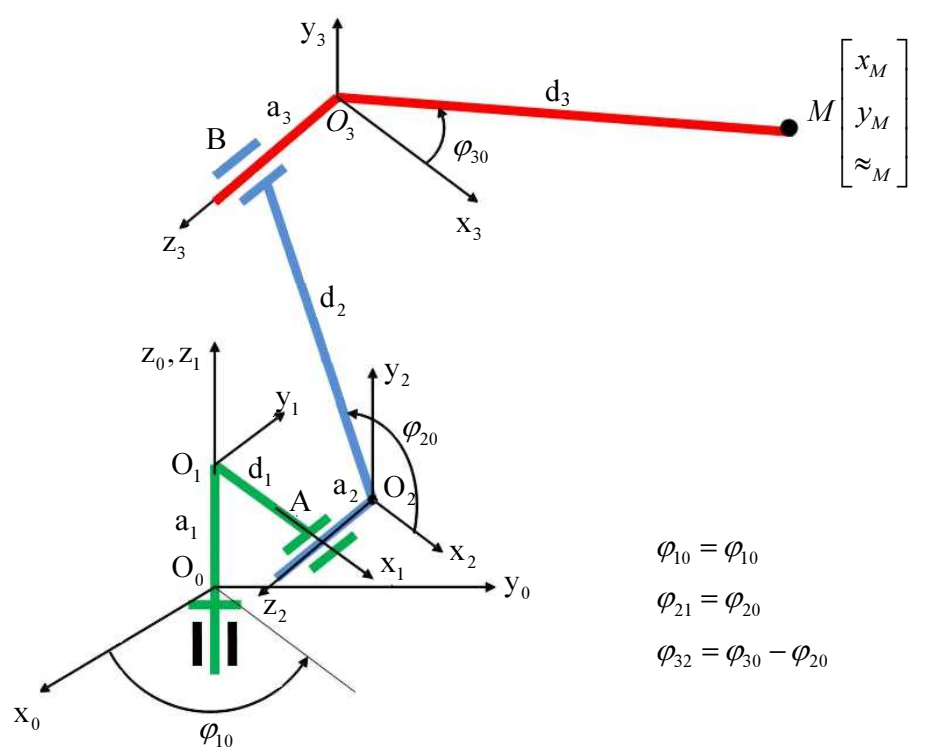

Fig. 2: The kinematic scheme of the spatial chain

Perhaps the method used may seem rather difficult, but compared to spatial matrix methods, it is extremely straightforward and direct, contributing to transforming the space movement into a flat, much easier to understand and studied movement.

In the system (4) we centralize all the transition relations from the plane to the spatial movement:

$$
\left\{\begin{array}{l}
x_{M}=\left(d_{1}+x_{M}^{P}\right) \cdot \cos \varphi_{10}-\left(a_{2}+a_{3}\right) \cdot \sin \varphi_{10} \\
y_{M}=\left(d_{1}+x_{M}^{P}\right) \cdot \sin \varphi_{10}+\left(a_{2}+a_{3}\right) \cdot \cos \varphi_{10} \\
z_{M}=a_{1}+y_{M}^{P}
\end{array}\right.
$$

Replacing in (4) the values of $x_{M}^{P}$ and $y_{M}^{P}$ obtaining the system of absolute spatial Equation 5:

$\left\{\begin{array}{l}x_{M}=\left(d_{1}+d_{2} \cdot \cos \varphi_{20}+d_{3} \cdot \cos \varphi_{30}\right) \cdot \cos \varphi_{10}-\left(a_{2}+a_{3}\right) \cdot \sin \varphi_{10} \\ y_{M}=\left(d_{1}+d_{2} \cdot \cos \varphi_{20}+d_{3} \cdot \cos \varphi_{30}\right) \cdot \sin \varphi_{10}+\left(a_{2}+a_{3}\right) \cdot \cos \varphi_{10}(5) \\ z_{M}=a_{1}+d_{2} \cdot \sin \varphi_{20}+d_{3} \cdot \sin \varphi_{30}\end{array}\right.$

For simpler determination of speeds and accelerations in the system (4) from which it departs, it is denoted $a_{2}+a_{3}$ by $a$, so that (4) acquires the simplified aspect (6): 


$$
\left\{\begin{array}{l}
x_{M}=\left(d_{1}+x_{M}^{P}\right) \cdot \cos \varphi_{10}-a \cdot \sin \varphi_{10} \\
y_{M}=\left(d_{1}+x_{M}^{P}\right) \cdot \sin \varphi_{10}+a \cdot \cos \varphi_{10} \\
z_{M}=a_{1}+y_{M}^{P}
\end{array}\right.
$$

The spatial positioning system (6) is derived from time and the spatial velocity system (7) is obtained:

$$
\left\{\begin{array}{l}
\dot{x}_{M}=\dot{x}_{M}^{P} \cdot \cos \varphi_{10}-\left(d_{1}+x_{M}^{P}\right) \cdot \sin \varphi_{10} \cdot \dot{\varphi}_{10}-a \cdot \cos \varphi_{10} \cdot \dot{\varphi}_{10} \\
\dot{y}_{M}=\dot{x}_{M}^{P} \cdot \sin \varphi_{10}+\left(d_{1}+x_{M}^{P}\right) \cdot \cos \varphi_{10} \cdot \dot{\varphi}_{10}-a \cdot \sin \varphi_{10} \cdot \dot{\varphi}_{10} \\
\dot{z}_{M}=\dot{y}_{M}^{P}
\end{array}\right.
$$

The space velocity system (7) derives from time and the spatial acceleration system (8) is obtained, which is restricted to the shape (9):

$$
\begin{aligned}
& \left\{\begin{array}{l}
\ddot{x}_{M}=\ddot{x}_{M}^{P} \cdot \cos \varphi_{10}-\dot{x}_{M}^{P} \cdot \sin \varphi_{10} \cdot \dot{\varphi}_{10}-\dot{x}_{M}^{P} \cdot \sin \varphi_{10} \cdot \dot{\varphi}_{10} \\
-\left(d_{1}+x_{M}^{P}\right) \cdot \cos \varphi_{10} \cdot \dot{\varphi}_{10}^{2}+a \cdot \sin \varphi_{10} \cdot \dot{\varphi}_{10}^{2} \\
\ddot{y}_{M}=\ddot{x}_{M}^{P} \cdot \sin \varphi_{10}+\dot{x}_{M}^{P} \cdot \cos \varphi_{10} \cdot \dot{\varphi}_{10}+\dot{x}_{M}^{P} \cdot \cos \varphi_{10} \cdot \dot{\varphi}_{10} \\
-\left(d_{1}+x_{M}^{P}\right) \cdot \sin \varphi_{10} \cdot \dot{\varphi}_{10}^{2}-a \cdot \cos \varphi_{10} \cdot \dot{\varphi}_{10}^{2} \\
\ddot{z}_{M}=\ddot{y}_{M}^{P}
\end{array}\right. \\
& \left\{\begin{array}{l}
\ddot{x}_{M}=\left[\ddot{x}_{M}^{P}-\left(d_{1}+x_{M}^{P}\right) \cdot \dot{\varphi}_{10}^{2}\right] \cdot \cos \varphi_{10} \\
-\left(2 \cdot \dot{x}_{M}^{P}-a \cdot \dot{\varphi}_{10}\right) \cdot \dot{\varphi}_{10} \cdot \sin \varphi_{10} \\
\ddot{y}_{M}=\left[\ddot{x}_{M}^{P}-\left(d_{1}+x_{M}^{P}\right) \cdot \dot{\varphi}_{10}^{2}\right] \cdot \sin \varphi_{10} \\
+\left(2 \cdot \dot{x}_{M}^{P}-a \cdot \dot{\varphi}_{10}\right) \cdot \dot{\varphi}_{10} \cdot \cos \varphi_{10} \\
\ddot{z}_{M}=\ddot{y}_{M}^{P}
\end{array}\right.
\end{aligned}
$$

The space velocity system (7) is restricted to the shape (10), which by using the notations $u$ and $v$ is rewritten in the simplified form (11) and the acceleration system (9) can be restricted to the shape (12), with the notations $w, t$ :

$$
\begin{aligned}
& \left\{\begin{array}{l}
\dot{x}_{M}=\left(\dot{x}_{M}^{P}-a \cdot \dot{\varphi}_{10}\right) \cdot \cos \varphi_{10}-\left(d_{1}+x_{M}^{P}\right) \cdot \dot{\varphi}_{10} \cdot \sin \varphi_{10} \\
\dot{y}_{M}=\left(\dot{x}_{M}^{P}-a \cdot \dot{\varphi}_{10}\right) \cdot \sin \varphi_{10}+\left(d_{1}+x_{M}^{P}\right) \cdot \dot{\varphi}_{10} \cdot \cos \varphi_{10} \\
\dot{z}_{M}=\dot{y}_{M}^{P}
\end{array}\right. \\
& \left\{\begin{array}{l}
\dot{x}_{M}=u \cdot \cos \varphi_{10}-v \cdot \sin \varphi_{10} \\
\dot{y}_{M}=u \cdot \sin \varphi_{10}+v \cdot \cos \varphi_{10} \\
\dot{z}_{M}=\dot{y}_{M}^{P} \\
u=\dot{x}_{M}^{P}-a \cdot \dot{\varphi}_{10} ; v=\left(d_{1}+x_{M}^{P}\right) \cdot \dot{\varphi}_{10}
\end{array}\right.
\end{aligned}
$$

$$
\left\{\begin{array}{l}
\ddot{x}_{M}=w \cdot \cos \varphi_{10}-t \cdot \sin \varphi_{10} \\
\ddot{y}_{M}=w \cdot \sin \varphi_{10}+t \cdot \cos \varphi_{10} \\
\ddot{z}_{M}=\ddot{y}_{M}^{P} \\
w=\ddot{x}_{M}^{P}-\left(d_{1}+x_{M}^{P}\right) \cdot \dot{\varphi}_{10}^{2} ; t=\left(2 \cdot \dot{x}_{M}^{P}-a \cdot \dot{\varphi}_{10}\right) \cdot \dot{\varphi}_{10}
\end{array}\right.
$$

Next, we will present the positions, velocities and spatial accelerations, all written down within the system (13):

$$
\left\{\begin{array}{l}
\text { Positions: } \\
x_{M}=s \cdot \cos \varphi_{10}-a \cdot \sin \varphi_{10} \\
y_{M}=s \cdot \sin \varphi_{10}+a \cdot \cos \varphi_{10} \\
z_{M}=a_{1}+y_{M}^{P} \\
\text { cu } s=d_{1}+x_{M}^{P} ; a=a_{2}+a_{3} \\
\text { Velocities : } \\
\dot{x}_{M}=u \cdot \cos \varphi_{10}-v \cdot \sin \varphi_{10} \\
\dot{y}_{M}=u \cdot \sin \varphi_{10}+v \cdot \cos \varphi_{10} \\
\dot{z}_{M}=\dot{y}_{M}^{P} \\
\text { cu } u=\dot{x}_{M}^{P}-a \cdot \dot{\varphi}_{10} ; v=\left(d_{1}+x_{M}^{P}\right) \cdot \dot{\varphi}_{10} \\
\text { Accelerations: } \\
\ddot{x}_{M}=w \cdot \cos \varphi_{10}-t \cdot \sin \varphi_{10} \\
\ddot{y}_{M}=w \cdot \sin \varphi_{10}+t \cdot \cos \varphi_{10} \\
\ddot{z}_{M}=\ddot{y}_{M}^{P} \\
\text { with } w=\ddot{x}_{M}^{P}-\left(d_{1}+x_{M}^{P}\right) \cdot \dot{\varphi}_{10}^{2} ; \quad t=\left(2 \cdot \dot{x}_{M}^{P}-a \cdot \dot{\varphi}_{10}\right) \cdot \dot{\varphi}_{10}
\end{array}\right.
$$

\section{Results}

The spatial position vector module of the end effector point $M$ in the fixed Cartesian space system is given by the relation (14):

$r_{M}=\sqrt{x_{M}^{2}+y_{M}^{2}+z_{M}^{2}}=\sqrt{s^{2}+a^{2}+\left(a_{1}+y_{M}^{P}\right)^{2}}$

The modulus of the absolute speed vector of point $M$ is obtained with the relation (15):

$v_{M}=\sqrt{\dot{x}_{M}^{2}+\dot{y}_{M}^{2}+\dot{z}_{M}^{2}}=\sqrt{u^{2}+v^{2}+\dot{y}_{M}^{P 2}}$

The M-point absolute acceleration vector module is obtained with relation (16):

$a_{M}=\sqrt{\ddot{x}_{M}^{2}+\ddot{y}_{M}^{2}+\ddot{z}_{M}^{2}}=\sqrt{w^{2}+t^{2}+\ddot{y}_{M}^{P 2}}$

In the system (17) a recapitulation of the three absolute spatial parameters of the $M$ point: Absolute displacement (or absolute position), absolute speed, absolute acceleration is made: 


$$
\left\{\begin{array}{l}
r_{M}=\sqrt{x_{M}^{2}+y_{M}^{2}+z_{M}^{2}}=\sqrt{s^{2}+a^{2}+\left(a_{1}+y_{M}^{P}\right)^{2}} \\
v_{M}=\sqrt{\dot{x}_{M}^{2}+\dot{y}_{M}^{2}+\dot{z}_{M}^{2}}=\sqrt{u^{2}+v^{2}+\dot{y}_{M}^{P 2}} \\
a_{M}=\sqrt{\ddot{x}_{M}^{2}+\ddot{y}_{M}^{2}+\ddot{z}_{M}^{2}}=\sqrt{w^{2}+t^{2}+\ddot{y}_{M}^{P 2}}
\end{array}\right.
$$

\section{Discussion}

Simple transition from plan to spatial computing can help us modify our work so that instead of performing all spatial matrices, let's study the planar system, then add the equation of transition from plane to spatial mode and so the same results will be obtained as if we had all the difficult spatial calculations done, practically just in plan, simplified. Man is accustomed to seeing the plan better than space, but especially to judge and reason more easily the plane phenomena than the spatial phenomena.

\section{Conclusion}

The anthropomorphic robots are part of the classical series of mechatronic systems, being in the form of arms and having at least three space rotation, to which other components may eventually be added, thus lengthening the entire kinematic chain. You can also add all the planetary or spatial rotating arms or others that are translating.

At the end we always have the end effector element that can be a manipulator, that is, a hand to grasp the objects, in which case one can speak of a prehensive device, that is a gripping device that today imitates very well a human hand even if it is one mechanical, may also be a painting, cutting or welding device, or one for machining.

The base support and schematics of all anthropomorphic robots remain the $3 \mathrm{R}$ space system. It has been presented in other works and studied matrix spatially, or more simply in a plan, but in this case, it is necessary to move from the working plane to the real space, or vice versa, passage that we will present in this study.

Projections of point $M$ on planar axes will be marked with the higher $P$ (Plan) index to distinguish them from the corresponding space axes.

Due to the fact that the vertical projection plane is removed from the $O \rho$ axis with a constant distance $a_{2}$ $+a_{3}$, (the vertical working plane does not project directly on the $O \rho$ axis, but on an axis parallel to it distal to the length $a_{2}+a_{3}$ ) the projection of the $M$ point on the horizontal plane of the space will not fall in $M$ 'but at the point $M^{\prime \prime}$.

Therefore, the projections of $\mathrm{M}$ on the axes $O x$ and $O y$ will not be those of point $M$ but those of point $M^{\prime \prime}$, according to the relations given by the system (2).

We want to remove the angle of $90^{\circ} \mathrm{C}$ from the relations (2), which had an important explanatory role in the understanding of the phenomenon, to see how the equation of transition from plane to spatial axes is written, here (in the horizontal plane of space) about a rotation, whose relations should not be automatically detained, but deduced logically, which is why we will immediately move from the logically determined system (2) to the convenient system (3), which will now be obtained from (2) the angle of $90^{\circ} \mathrm{C}$ from the trigonometric relations.

Perhaps the method used may seem rather difficult, but compared to spatial matrix methods, it is extremely straightforward and direct, contributing to transforming the space movement into a flat, much easier to understand and studied movement. In the system (4) we centralize all the transition relations from the plane to the spatial movement.

\section{Acknowledgement}

This text was acknowledged and appreciated by Dr. Veturia CHIROIU Honorific member of Technical Sciences Academy of Romania (ASTR) PhD supervisor in Mechanical Engineering.

\section{Funding Information}

Research contract: 1-Research contract: Contract number 36-5-4D/1986 from 24IV1985, beneficiary CNST RO (Romanian National Center for Science and Technology) Improving dynamic mechanisms.

2-Contract research integration. 19-91-3 from 29.03.1991; Beneficiary: MIS; TOPIC: Research on designing mechanisms with bars, cams and gears, with application in industrial robots.

3-Contract research. GR 69/10.05.2007: NURC in 2762; theme 8: Dynamic analysis of mechanisms and manipulators with bars and gears.

4-Labor contract, no. 35/22.01.2013, the UPB, "Stand for reading performance parameters of kinematics and dynamic mechanisms, using inductive and incremental encoders, to a Mitsubishi Mechatronic System" "PN-IIIN-CI-2012-1-0389".

All these matters are copyrighted! Copyrights: 394qodGnhhtej, from 17-02-2010 13:42:18; 463vpstuCGsiy, from 20-03-2010 12:45:30; 631sqfsgqvutm, from 24-05-2010 16:15:22; 933CrDztEfqow, from 07-01-2011 13:37:52.

\section{Author's Contributions}

This section should state the contributions made by each author in the preparation, development and publication of this manuscript.

\section{Ethics}

Authors should address any ethical issues that may arise after the publication of this manuscript. 


\section{References}

Antonescu, P. and F. Petrescu, 1985. An analytical method of synthesis of cam mechanism and flat stick. Proceedings of the 4th International Symposium on Theory and Practice of Mechanisms, (TPM' 89), Bucharest.

Antonescu, P. and F. Petrescu, 1989. Contributions to kinetoplast dynamic analysis of distribution mechanisms. Bucharest.

Antonescu, P., M. Oprean and F. Petrescu, 1985a. Contributions to the synthesis of oscillating cam mechanism and oscillating flat stick. Proceedings of the 4th International Symposium on Theory and Practice of Mechanisms, (TPM' 85), Bucharest.

Antonescu, P., M. Oprean and F. Petrescu, 1985b. At the projection of the oscillate cams, there are mechanisms and distribution variables. Proceedings of the 5th Conference of Engines, Automobiles, Tractors and Agricultural Machines, (TAM' 58), Imotors and cars, Brasov.

Antonescu, P., M. Oprean and F. Petrescu, 1986. Projection of the profile of the rotating camshaft acting on the oscillating plate with disengagement. Proceedings of the 3rd National Computer-aided Design Symposium in the field of Mechanisms and Machine Parts, (MMP' 86), Brasov.

Antonescu, P., M. Oprean and F. Petrescu, 1987. Dynamic analysis of the cam distribution mechanisms. Proceedings of the 7th National Symposium on Industrial Robots and Space Mechanisms, (RSM' 87), Bucharest.

Antonescu, P., M. Oprean and F. Petrescu, 1988. Analytical synthesis of Kurz profile, rotating the flat cam. Mach, Build. Rev.

Antonescu, P., F. Petrescu and O. Antonescu, 1994. Contributions to the synthesis of the rotating cam mechanism and the tip of the balancing tip. Brasov.

Antonescu, P., F. Petrescu and D. Antonescu, 1997. Geometrical synthesis of the rotary cam and balance tappet mechanism. Bucharest. 3: 23-23.

Antonescu, P., F. Petrescu and O. Antonescu, 2000a. Contributions to the synthesis of the rotary disc-cam profile. Proceedings of the 8th International Conference on the Theory of Machines and Mechanisms, (TMM' 00), Liberec, Czech Republic, pp: 51-56.

Antonescu, P., F. Petrescu and O. Antonescu, 2000b. Synthesis of the rotary cam profile with balance follower. Proceedings of the 8th Symposium on Mechanisms and Mechanical Transmissions, (MMT' 00), Timişoara, pp: 39-44.

Antonescu, P., F. Petrescu and O. Antonescu, 2001. Contributions to the synthesis of mechanisms with rotary disc-cam. Proceedings of the 8th IFToMM International Symposium on Theory of Machines and Mechanisms, (TMM' 01), Bucharest, ROMANIA, pp: 31-36.
Aversa, R., R.V.V. Petrescu, A. Apicella and F.I.T. Petrescu, 2017a. Nano-diamond hybrid materials for structural biomedical application. Am. J. Biochem. Biotechnol., 13: 34-41. DOI: 10.3844/ajbbsp.2017.34.41

Aversa, R., R.V. Petrescu, B. Akash, R.B. Bucinell and J.M. Corchado et al., 2017b. Kinematics and forces to a new model forging manipulator. Am. J. Applied Sci., 14: 60-80. DOI: 10.3844/ajassp.2017.60.80

Aversa, R., R.V. Petrescu, A. Apicella, I.T.F. Petrescu and J.K. Calautit et al., 2017c. Something about the $\mathrm{V}$ engines design. Am. J. Applied Sci., 14: 34-52. DOI: 10.3844/ajassp.2017.34.52

Aversa, R., D. Parcesepe, R.V.V. Petrescu, F. Berto and G. Chen et al., 2017d. Process ability of bulk metallic glasses. Am. J. Applied Sci., 14: 294-301. DOI: 10.3844/ajassp.2017.294.301

Aversa, R., R.V.V. Petrescu, B. Akash, R.B. Bucinell and J.M. Corchado et al., 2017e. Something about the balancing of thermal motors. Am. J. Eng. Applied Sci., 10: 200.217. DOI: 10.3844/ajeassp.2017.200.217

Aversa, R., F.I.T. Petrescu, R.V. Petrescu and A. Apicella, 2016a. Biomimetic FEA bone modeling for customized hybrid biological prostheses development. Am. J. Applied Sci., 13: 1060-1067. DOI: 10.3844/ajassp.2016.1060.1067

Aversa, R., D. Parcesepe, R.V. Petrescu, G. Chen and F.I.T. Petrescu et al., 2016b. Glassy amorphous metal injection molded induced morphological defects. Am. J. Applied Sci., 13: 1476-1482. DOI: 10.3844/ajassp.2016.1476.1482

Aversa, R., R.V. Petrescu, F.I.T. Petrescu and A. Apicella, 2016c. Smart-factory: Optimization and process control of composite centrifuged pipes. Am. J. Applied Sci., 13: 1330-1341.

DOI: 10.3844/ajassp.2016.1330.1341

Aversa, R., F. Tamburrino, R.V. Petrescu, F.I.T. Petrescu and M. Artur et al., 2016d. Biomechanically inspired shape memory effect machines driven by muscle like acting NiTi alloys. Am. J. Applied Sci., 13: 1264-1271. DOI: 10.3844/ajassp.2016.1264.1271

Aversa, R., E.M. Buzea, R.V. Petrescu, A. Apicella and M. Neacsa et al., 2016e. Present a mechatronic system having able to determine the concentration of carotenoids. Am. J. Eng. Applied Sci., 9: 1106-1111. DOI: 10.3844/ajeassp.2016.1106.1111

Aversa, R., R.V. Petrescu, R. Sorrentino, F.I.T. Petrescu and A. Apicella, 2016f. Hybrid ceramo-polymeric nanocomposite for biomimetic scaffolds design and preparation. Am. J. Eng. Applied Sci., 9: 1096-1105. DOI: 10.3844/ajeassp.2016.1096.1105

Aversa, R., V. Perrotta, R.V. Petrescu, C. Misiano and F.I.T. Petrescu et al., 2016g. From structural colors to super-hydrophobicity and achromatic transparent protective coatings: Ion plating plasma assisted $\mathrm{TiO}_{2}$ and $\mathrm{SiO}_{2}$ Nano-film deposition. Am. J. Eng. Applied Sci., 9: 1037-1045. DOI: 10.3844/ajeassp.2016.1037.1045 
Aversa, R., R.V. Petrescu, F.I.T. Petrescu and A. Apicella, 2016h. Biomimetic and evolutionary design driven innovation in sustainable products development. Am. J. Eng. Applied Sci., 9: 1027-1036. DOI: 10.3844/ajeassp.2016.1027.1036

Aversa, R., R.V. Petrescu, A. Apicella and F.I.T. Petrescu, 2016i. Mitochondria are naturally micro robots-a review. Am. J. Eng. Applied Sci., 9: 991-1002. DOI: 10.3844/ajeassp.2016.991.1002

Aversa, R., R.V. Petrescu, A. Apicella and F.I.T. Petrescu, 2016j. We are addicted to vitamins $\mathrm{C}$ and E-A review. Am. J. Eng. Applied Sci., 9: 1003-1018. DOI: 10.3844/ajeassp.2016.1003.1018

Aversa, R., R.V. Petrescu, A. Apicella and F.I.T. Petrescu, 2016k. Physiologic human fluids and swelling behavior of hydrophilic biocompatible hybrid ceramo-polymeric materials. Am. J. Eng. Applied Sci., 9: 962-972. DOI: 10.3844/ajeassp.2016.962.972

Aversa, R., R.V. Petrescu, A. Apicella and F.I.T. Petrescu, 20161. One can slow down the aging through antioxidants. Am. J. Eng. Applied Sci., 9: 1112-1126. DOI: 10.3844/ajeassp.2016.1112.1126

Aversa, R., R.V. Petrescu, A. Apicella and F.I.T. Petrescu, 2016m. About homeopathy or «Similia similibus curentur $\gg$. Am. J. Eng. Applied Sci., 9: 1164-1172. DOI: 10.3844/ajeassp.2016.1164.1172

Aversa, R., R.V. Petrescu, A. Apicella and F.I.T. Petrescu, 2016n. The basic elements of life's. Am. J. Eng. Applied Sci., 9: 1189-1197. DOI: 10.3844 /ajeassp.2016.1189.1197

Aversa, R., F.I.T. Petrescu, R.V. Petrescu and A. Apicella, 2016o. Flexible stem trabecular prostheses. Am. J. Eng. Applied Sci., 9: 1213-1221. DOI: 10.3844 /ajeassp.2016.1213.1221

Berto, F., R.V.V. Petrescu and F.I.T. Petrescu, 2016a. A review of recent results on $3 \mathrm{D}$ effects. Am. J. Eng. Applied Sci., 9: 1247-1260. DOI: 10.3844/ajeassp.2016.1247.1260

Berto, F., R.V.V. Petrescu and F.I.T. Petrescu, $2016 \mathrm{~b}$. Three-dimensional in bonded joints: A short review. Am. J. Eng. Applied Sci., 9: 1261-1268. DOI: 10.3844/ajeassp.2016.1261.1268

Berto, F., A. Gagani, R.V.V. Petrescu and F.I.T. Petrescu, 2016c. Key-hole notches in isostatic graphite: A review of some recent data. Am. J. Eng. Applied Sci., 9: 1292-1300. DOI: 10.3844/ajeassp.2016.1292.1300

Berto, F., A. Gagani, R. Aversa, R.V.V. Petrescu and A. Apicella et al., 2016d. Multiaxial fatigue strength to notched specimens made of 40CrMoV13.9. Am. J. Eng. Applied Sci., 9: 1269-1291. DOI: 10.3844/ajeassp.2016.1269.1291

Cao, W., H. Ding, Z. Bin and C. Ziming, 2013. New structural representation and digital-analysis platform for symmetrical parallel mechanisms. Int. J. Adv. Robotic Sys. DOI: 10.5772/56380
Comanescu, A., 2010. Bazele Modelarii Mecanismelor. 1st Edn., E. Politeh. Press, Bucureşti, pp: 274.

Dong, H., N. Giakoumidis, N. Figueroa and N. Mavridis, 2013. Approaching behaviour monitor and vibration indication in developing a General Moving Object Alarm System (GMOAS). Int. J. Adv. Robotic Sys. DOI: $10.5772 / 56586$

Franklin, D.J., 1930. Ingenious Mechanisms for Designers and iNventors. 1st Edn., Industrial Press Publisher.

He, B., Z. Wang, Q. Li, H. Xie and R. Shen, 2013. An analytic method for the kinematics and dynamics of a multiple-backbone continuum robot. IJARS. DOI: $10.5772 / 54051$

Lee, B.J., 2013. Geometrical derivation of differential kinematics to calibrate model parameters of flexible manipulator. Int. J. Adv. Robotic Sys. DOI: $10.5772 / 55592$

Lin, W., B. Li, X. Yang and D. Zhang, 2013. Modelling and control of inverse dynamics for a 5-DOF parallel kinematic polishing machine. Int. J. Adv. Robotic Sys. DOI: 10.5772/54966

Liu, H., W. Zhou, X. Lai and S. Zhu, 2013. An efficient inverse kinematic algorithm for a PUMA560structured robot manipulator. IJARS. DOI: $10.5772 / 56403$

Mirsayar, M.M., V.A. Joneidi, R.V.V. Petrescu, F.I.T. Petrescu and F. Berto, 2017. Extended MTSN criterion for fracture analysis of soda lime glass. Eng. Fracture Mechan., 178: 50-59. DOI: 10.1016/j.engfracmech.2017.04.018

Padula, F. and V. Perdereau, 2013. An on-line path planner for industrial manipulators. Int. J. Adv. Robotic Sys. DOI: 10.5772/55063

Perumaal, S. and N. Jawahar, 2013. Automated trajectory planner of industrial robot for pick-andplace task. IJARS. DOI: 10.5772/53940

Petrescu, F. and R. Petrescu, 1995a. Contributions to optimization of the polynomial motion laws of the stick from the internal combustion engine distribution mechanism. Bucharest, 1: 249-256.

Petrescu, F. and R. Petrescu, 1995b. Contributions to the synthesis of internal combustion engine distribution mechanisms. Bucharest, 1: 257-264.

Petrescu, F. and R. Petrescu, 1997a. Dynamics of cam mechanisms (exemplified on the classic distribution mechanism). Bucharest, 3: 353-358.

Petrescu, F. and R. Petrescu, 1997b. Contributions to the synthesis of the distribution mechanisms of internal combustion engines with a Cartesian coordinate method. Bucharest, 3: 359-364.

Petrescu, F. and R. Petrescu, 1997c. Contributions to maximizing polynomial laws for the active stroke of the distribution mechanism from internal combustion engines. Bucharest, 3: 365-370. 
Petrescu, F. and R. Petrescu, 2000a. Synthesis of distribution mechanisms by the rectangular (Cartesian) coordinate method. Proceedings of the 8th National Conference on International Participation, (CIP' 00), Craiova, Romania, pp: 297-302.

Petrescu, F. and R. Petrescu, 2000b. The design (synthesis) of cams using the polar coordinate method (triangle method). Proceedings of the 8th National Conference on International Participation, (CIP' 00), Craiova, Romania, pp: 291-296.

Petrescu, F. and R. Petrescu, 2002a. Motion laws for cams. Proceedings of the International Computer Assisted Design, National Symposium with Participation, (SNP' 02), Braşov, pp: 321-326.

Petrescu, F. and R. Petrescu, 2002b. Camshaft dynamics elements. Proceedings of the International Computer Assisted Design, National Participation Symposium, (SNP' 02), Braşov, pp: 327-332.

Petrescu, F. and R. Petrescu, 2003. Some elements regarding the improvement of the engine design. Proceedings of the National Symposium, Descriptive Geometry, Technical Graphics and Design, (GTD' 03), Braşov, pp: 353-358.

Petrescu, F. and R. Petrescu, 2005a. The cam design for a better efficiency. Proceedings of the International Conference on Engineering Graphics and Design, (EGD' 05), Bucharest, pp: 245-248.

Petrescu, F. and R. Petrescu, 2005b. Contributions at the dynamics of cams. Proceedings of the 9th IFToMM International Symposium on Theory of Machines and Mechanisms, (TMM' 05), Bucharest, Romania, pp: 123-128.

Petrescu, F. and R. Petrescu, 2005c. Determining the dynamic efficiency of cams. Proceedings of the 9th IFToMM International Symposium on Theory of Machines and Mechanisms, (TMM' 05), Bucharest, Romania, pp: 129-134.

Petrescu, F. and R. Petrescu, 2005d. An original internal combustion engine. Proceedings of the 9th IFToMM International Symposium on Theory of Machines and Mechanisms, (TMM' 05), Bucharest, Romania, pp: $135-140$.

Petrescu, F. and R. Petrescu, 2005e. Determining the mechanical efficiency of Otto engine's mechanism. Proceedings of the 9th IFToMM International Symposium on Theory of Machines and Mechanisms, (TMM' 05), Bucharest, Romania, pp: 141-146.

Petrescu, F.I. and R.V. Petrescu, 2011. Mechanical Systems, Serial and Parallel (Romanian). 1st Edn., LULU Publisher, London, UK, pp: 124.

Petrescu, F.I. and R.V. Petrescu, 2012a. Kinematics of the planar quadrilateral mechanism. ENGEVISTA, 14: 345-348.

Petrescu, F.I. and R.V. Petrescu, 2012b MecatronicaSisteme Seriale si Paralele. 1st Edn., Create Space Publisher, USA, pp: 128.
Petrescu, F.I. and R.V. Petrescu, 2013a. Cinematics of the 3R dyad. ENGEVISTA, 15: 118-124.

Petrescu, F.I. and R.V. Petrescu, 2013b. Forces and efficiency of cams. Int. Rev. Mech. Eng.

Petrescu, F.I. and R.V. Petrescu, 2016a. Parallel moving mechanical systems kinematics. ENGEVISTA, 18: 455-491.

Petrescu, F.I. and R.V. Petrescu, 2016b. Direct and inverse kinematics to the anthropomorphic robots. ENGEVISTA, 18: 109-124.

Petrescu, F.I. and R.V. Petrescu, 2016c. Dynamic cinematic to a structure 2R. Revista Geintec-Gestao Inovacao E Tecnol., 6: 3143-3154.

Petrescu, R.V., R. Aversa, A. Apicella and F.I. Petrescu, 2016. Future medicine services robotics. Am. J. Eng. Applied Sci., 9: 1062-1087. DOI: 10.3844/ajeassp.2016.1062.1087

Petrescu, F.I., B. Grecu, A. Comanescu and R.V. Petrescu, 2009. Some mechanical design elements. Proceeding of the International Conference on Computational Mechanics and Virtual Engineering, (MVE' 09), Braşov, pp: 520-525.

Petrescu, F.I., 2011. Teoria Mecanismelor si a Masinilor: Curs Si Aplicatii. 1st Edn., CreateSpace Independent Publishing Platform. ISBN-10: 1468015826. pp: 432.

Petrescu, F.I.T., 2015a. Geometrical synthesis of the distribution mechanisms. Am. J. Eng. Applied Sci., 8: 63-81. DOI: 10.3844/ajeassp.2015.63.81

Petrescu, F.I.T., 2015b. Machine motion equations at the internal combustion heat engines. Am. J. Eng. Applied Sci., 8: 127-137. DOI: 10.3844 ajeassp.2015.127.137

Petrescu, R.V., R. Aversa, B. Akash, R. Bucinell and J. Corchado et al., 2017a. Yield at thermal engines internal combustion. Am. J. Eng. Applied Sci., 10: 243-251.

DOI: 10.3844/ajeassp.2017.243.251

Petrescu, R.V., R. Aversa, B. Akash, B. Ronald and J. Corchado et al., 2017b. Velocities and accelerations at the 3R mechatronic systems. Am. J. Eng. Applied Sci., 10: 252-263.

DOI: 10.3844 /ajeassp.2017.252.263

Petrescu, R.V., R. Aversa, B. Akash, R. Bucinell and J. Corchado et al., 2017c. Anthropomorphic solid structures n-r kinematics. Am. J. Eng. Applied Sci., 10: 279-291. DOI: 10.3844/ajeassp.2017.279.291

Petrescu, R.V., R. Aversa, B. Akash, R. Bucinell and J. Corchado et al., 2017d. Inverse kinematics at the anthropomorphic robots, by a trigonometric method. Am. J. Eng. Applied Sci., 10: 394-411. DOI: 10.3844/ajeassp.2017.394.411

Petrescu, R.V., R. Aversa, B. Akash, R. Bucinell and J. Corchado et al., 2017e. Forces at internal combustion engines. Am. J. Eng. Applied Sci., 10: 382-393. DOI: 10.3844/ajeassp.2017.382.393 
Petrescu, R.V., R. Aversa, B. Akash, R. Bucinell and J. Corchado et al., 2017f. Gears-Part I. Am. J. Eng. Applied Sci., 10: 457-472.

DOI: 10.3844/ajeassp.2017.457.472

Petrescu, R.V., R. Aversa, B. Akash, R. Bucinell and J. Corchado et al., 2017g. Gears-part II. Am. J. Eng. Applied Sci., 10: 473-483.

DOI: 10.3844/ajeassp.2017.473.483

Petrescu, R.V., R. Aversa, B. Akash, R. Bucinell and J. Corchado et al., 2017h. Cam-gears forces, velocities, powers and efficiency. Am. J. Eng. Applied Sci., 10: 491-505.

DOI: 10.3844/ajeassp.2017.491.505

Petrescu, R.V., R. Aversa, B. Akash, R. Bucinell and J. Corchado et al., 2017i. Dynamics of mechanisms with cams illustrated in the classical distribution. Am. J. Eng. Applied Sci., 10: 551-567. DOI: 10.3844/ajeassp.2017.551.567

Petrescu, R.V., R. Aversa, B. Akash, R. Bucinell and J. Corchado et al., 2017j. Testing by nondestructive control. Am. J. Eng. Applied Sci., 10: 568-583. DOI: 10.3844/ajeassp.2017.568.583

Petrescu, R.V., R. Aversa, A. Apicella and F.I.T. Petrescu, 2017k. Transportation engineering. Am. J. Eng. Applied Sci., 10: 685-702. DOI: 10.3844/ajeassp.2017.685.702

Petrescu, R.V., R. Aversa, S. Kozaitis, A. Apicella and F.I.T. Petrescu, 2017l. The quality of transport and environmental protection, part I. Am. J. Eng. Applied Sci., 10: 738-755. DOI: 10.3844/ajeassp.2017.738.755

Petrescu, R.V., R. Aversa, B. Akash, R. Bucinell and J. Corchado et al., $2017 \mathrm{~m}$. Modern propulsions for aerospace-a review. J. Aircraft Spacecraft Technol., 1: 1-8. DOI: $10.3844 /$ jastsp.2017.1.8

Petrescu, R.V., R. Aversa, B. Akash, R. Bucinell and J. Corchado et al., 2017n. Modern propulsions for aerospace-part II. J. Aircraft Spacecraft Technol., 1: 9-17. DOI: 10.3844/jastsp.2017.9.17

Petrescu, R.V., R. Aversa, B. Akash, R. Bucinell and J. Corchado et al., 2017o. History of aviation-a short review. J. Aircraft Spacecraft Technol., 1: 30-49. DOI: 10.3844 /jastsp.2017.30.49

Petrescu, R.V., R. Aversa, B. Akash, R. Bucinell and J. Corchado et al., 2017p. Lockheed martin-a short review. J. Aircraft Spacecraft Technol., 1: 50-68. DOI: 10.3844 /jastsp.2017.50.68

Petrescu, R.V., R. Aversa, B. Akash, J. Corchado and F. Berto et al., 2017q. Our universe. J. Aircraft Spacecraft Technol., 1: 69-79. DOI: 10.3844/jastsp.2017.69.79

Petrescu, R.V., R. Aversa, B. Akash, J. Corchado and F. Berto et al., 2017r. What is a UFO? J. Aircraft Spacecraft Technol., 1: 80-90. DOI: 10.3844 jastsp.2017.80.90

Petrescu, R.V., R. Aversa, B. Akash, J. Corchado and F. Berto et al., 2017s. About bell helicopter FCX-001 concept aircraft-a short review. J. Aircraft Spacecraft Technol., 1: 91-96. DOI: 10.3844/jastsp.2017.91.96
Petrescu, R.V., R. Aversa, B. Akash, J. Corchado and F. Berto et al., 2017t. Home at airbus. J. Aircraft Spacecraft Technol., 1: 97-118. DOI: $10.3844 /$ jastsp.2017.97.118

Petrescu, R.V., R. Aversa, B. Akash, J. Corchado and F. Berto et al., $2017 \mathrm{u}$. Airlander. J. Aircraft Spacecraft Technol., 1: 119-148. DOI: 10.3844/jastsp.2017.119.148

Petrescu, R.V., R. Aversa, B. Akash, J. Corchado and F. Berto et al., 2017v. When boeing is dreaming-a review. J. Aircraft Spacecraft Technol., 1: 149-161. DOI: 10.3844/jastsp.2017.149.161

Petrescu, R.V., R. Aversa, B. Akash, J. Corchado and F. Berto et al., 2017w. About Northrop Grumman. J. Aircraft Spacecraft Technol., 1: 162-185. DOI: $10.3844 /$ jastsp.2017.162.185

Petrescu, R.V., R. Aversa, B. Akash, J. Corchado and F. Berto et al., 2017x. Some special aircraft. J. Aircraft Spacecraft Technol., 1: 186-203. DOI: $10.3844 /$ jastsp.2017.186.203

Petrescu, R.V., R. Aversa, B. Akash, J. Corchado and F. Berto et al., 2017y. About helicopters. J. Aircraft Spacecraft Technol., 1: 204-223. DOI: 10.3844/jastsp.2017.204.223

Petrescu, R.V., R. Aversa, B. Akash, F. Berto and A. Apicella et al., 2017z. The modern flight. J. Aircraft Spacecraft Technol., 1: 224-233. DOI: $10.3844 /$ jastsp.2017.224.233

Petrescu, R.V., R. Aversa, B. Akash, F. Berto and A. Apicella et al., 2017aa. Sustainable energy for aerospace vessels. J. Aircraft Spacecraft Technol., 1: 234-240. DOI: 10.3844/jastsp.2017.234.240

Petrescu, R.V., R. Aversa, B. Akash, F. Berto and A. Apicella et al., 2017ab. Unmanned helicopters. J. Aircraft Spacecraft Technol., 1: 241-248. DOI: $10.3844 /$ jastsp.2017.241.248

Petrescu, R.V., R. Aversa, B. Akash, F. Berto and A. Apicella et al., 2017ac. Project HARP. J. Aircraft Spacecraft Technol., 1: 249-257. DOI: 10.3844/jastsp.2017.249.257

Petrescu, R.V., R. Aversa, B. Akash, F. Berto and A. Apicella et al., 2017ad. Presentation of romanian engineers who contributed to the development of global aeronautics-part I. J. Aircraft Spacecraft Technol., 1: 258-271. DOI: $10.3844 /$ jastsp.2017.258.271

Petrescu, R.V., R. Aversa, B. Akash, F. Berto and A. Apicella et al., 2017ae. A first-class ticket to the planet mars, please. J. Aircraft Spacecraft Technol., 1: 272-281. DOI: 10.3844/jastsp.2017.272.281 